\title{
Assessment of Pomegranate Juice as an Alternative "Substrate" for Probiotic Delivery. Recent Advances and Prospects
}

\author{
Stavros Kazakos, Ioanna Mantzourani and Stavros Plessas *(D) \\ Laboratory of Food Processing, Faculty of Agriculture Development, Democritus University of Thrace, \\ 68200 Orestiada, Greece; stkazak@yahoo.gr (S.K.); imantzou@agro.duth.gr (I.M.) \\ * Correspondence: splessas@agro.duth.gr; Tel./Fax: +30-255-204-1141
}

Received: 27 January 2020; Accepted: 11 February 2020; Published: 12 February 2020

\begin{abstract}
The probiotic products in the market are mostly milk-based products, such as yoghurts, cheese and fermented milk. However, lately, there has been an increasing demand for non-dairy probiotic products due to various reasons such as allergies, lactose intolerance, high cholesterol content and consumers turning to more natural foods. Fruit juices are considered as an appropriate new substrate for probiotic delivery. From these, pomegranate (Punica granatum L.) is gaining more attention in recent years. Pomegranate is a fruit known since ancient times for its therapeutic qualities, such as antioxidant, anti-inflammatory, antibacterial, antiviral and antitumor properties, among others. Pomegranate juice contains a range of bioactive compounds such as phytochemicals, like polyphenols, ellagitannins, anthocyanins and punicalagins. The fermentation of the juice with probiotic strains seems to provide beverages of high nutritional values and accepted organoleptic quality. Therefore, the aim of this comprehensive review is to present an overview of the innovative in vitro and in vivo assays that have taken place regarding fermentation of pomegranate juice by probiotic bacteria. In addition, various drawbacks are underlined and solutions are proposed and discussed regarding the feasibility of pomegranate juice as an alternative substrate for probiotic delivery.
\end{abstract}

Keywords: probiotic; functional foods; pomegranate juice

\section{Introduction}

Increased consumer concern about safer and more beneficial food for humans has boosted the demand for the production of functional foods and beverages. Functional foods are food products, part of the normal diet, which may provide beneficial health effects or possible reduction of risk of disease to consumers [1].

More specifically, functional foods are mainly categorized as: i) beverages with natural bioactive compounds (e.g., dietary fibre), ii) beverages with extra added bioactive compounds (e.g., antioxidants) and iii) introduced nutrient ingredients to conventional beverages (e.g., prebiotics). Functional foods and beverages of all kinds should not be considered as medicines and should be consumed only as part of a normal daily diet [1]. Likewise, functional beverages are considered as a fast-growing category of functional foods that includes juices enriched with herbs, vitamins, aminoacids or/and vegetables. Their health benefits are numerous and namely include anti-inflammatory, anti-hypertensive [2], antitumor [3], antibacterial, antiviral and antioxidant activities [4].

The objective of this comprehensive review is to gain insights into the in vivo and in vitro trials that have taken place on the application of pomegranate juice in lactic acid fermentation through probiotic bacteria up until now, and discuss respective advantages and disadvantages. 


\section{Probiotics, Prebiotics and Synbiotics}

Probiotics are defined as live single or mixed microbial cultures able to improve the composition of gut microbiota to defined strains with immunomodulatory potential [1]. Various probiotic strains have been categorized, mostly belonging to Leuconostoc spp., Lactobacillus spp., Pediococcus spp., Weissella spp., Bifidobacterium spp. and Lactococcus spp. Many of them are part of fermented dairy and non-dairy products, like yogurt, kefir and cheese [5].

Prebiotics are nondigestible or low-digestible food ingredients in that they stimulate the growth of some probiotic bacteria in the colon [6,7]. Prebiotics are considered a range of di-, oligo- and polysaccharides, some resistant starches and sugar polyols [8]. The main prebiotics included in the human diet are galacto-oligosaccharides, fructo-oligosaccharides, inulin, lactulose and malto-oligosaccharides [1]. Prebiotics have been applied to bakery products, breakfast cereals, cakes, beverages, dairy products, table spreads, butter-like products, cream cheeses, chocolate products, yogurts and fruit juices [9].

Nowadays, the combination of probiotics and prebiotics (synbiotics) is gaining space in the market, mostly because of their synergistic effects when applied to food products [9]. The main advantage of their development is to help probiotics to overcome possible survival difficulties in the host [7]. Several products of this category have been launched in markets with promising results, such as Raftiloses P95 in combination with L. rhamnosus, Bifidobacterium spp., L. acidophilus and L. casei, and others [10,11].

\section{Fruit Juices as Substrates for Probiotic Delivery}

Dairy-fermented products are considered, nowadays, as optimum carriers of probiotic strains. However, in the last decade, several reasons, such as (i) lactose-intolerance, (ii) allergies after dairy products consumption and (iii) a general emerging food trend towards a vegan diet, have turned research to the production of innovative, alternative mediums for probiotic delivery $[12,13]$. Regarding this new trend, fruit and vegetables have started to gain the attention from the food industry and consumers. The contents of fruits and vegetables are rich in nutrient ingredients, vitamins and minerals. Fermented fruits and vegetables are mostly part of the Asian food tradition more than in Western food cultures. This fact can be explained by the variety of fermented products consumed in Asian countries such as tempeh, kimchi, gundruk, khalpi, sinki and sauerkraut [14].

Probiotic beverages have been produced with various fruit juices such as apples, pineapples, pears and carrots through lactic acid fermentation with probiotic bacteria as it can be observed in the literature [15-19].

Similarly, commercially probiotic juices are proposed by many manufactures lately, verifying the high interest and significance of these new novel products (Table 1). Various juices have been applied either in single or mixed from with other juices and many probiotic bacteria, mainly lactic acid bacteria (LAB) have been used in the respective lactic acid fermentation of the juices. In this aspect, pomegranate juice also poses a high place in this new innovative trend (Table 1).

Table 1. Commercially available probiotic juices (references [20-22]).

\begin{tabular}{|c|c|c|}
\hline Product Name and Manufacture & Probiotic Strain(s) & Fruit Juice \\
\hline $\begin{array}{c}\text { BiolaR } \\
\text { (TINE BA, Norway) }\end{array}$ & L.rhamnosus GG & $\begin{array}{l}\text { Mixture of apple/pear and, orange/mango } \\
\text { juice with } 95 \% \text { fruit and no added sugar }\end{array}$ \\
\hline $\begin{array}{c}\text { Bio-Live Gold \& Dark } \\
\text { (Bio-Live/Microbz Ltd., UK) }\end{array}$ & $\begin{array}{l}\text { Mixtures of } 13 \text { strains including } \\
\text { L.acidophilus, L.bulgaricus, L.casei, } \\
\text { L.plantarum, L.fermentum, } \\
\text { Lactococcus lactis, Bacillus subtilis, } \\
\text { B.bifidum, B.longum, B.infantis, } \\
\text { Streptococcus thermophilus, } \\
\text { Comobcillus and S. cerevisiae }\end{array}$ & $\begin{array}{c}\text { Mixture of fruit juices such as acai berry, } \\
\text { cherry, goji, noni, pomegranate, lemon, and } \\
\text { various herbs }\end{array}$ \\
\hline $\begin{array}{c}\text { Bravo Friscus } \\
\text { (Probi AB, Sweden) }\end{array}$ & $\begin{array}{l}\text { L.plantarum HEAL9 and } \\
\text { L.paracasei 8700:2 }\end{array}$ & Orange, apple and tropical fruit juices \\
\hline
\end{tabular}


Table 1. Cont.

\begin{tabular}{|c|c|c|}
\hline Product Name and Manufacture & Probiotic Strain(s) & Fruit Juice \\
\hline $\begin{array}{l}\text { Gefilus Fruit drinks } \\
\text { (Valio Ltd., Finland) }\end{array}$ & $\begin{array}{c}\text { L.rhamnosus GG and } \\
\text { Propionibacterium freudenreichii } \\
\text { ssp. shermanii JS }\end{array}$ & Berries \\
\hline $\begin{array}{l}\text { Golden Circle Healthy Life } \\
\text { Probiotic Juice (Golden Circle, } \\
\text { Australia) }\end{array}$ & $\begin{array}{l}\text { L.paracasei } 8700: 2 \text { and } \\
\text { L.plantarum HEAL9 }\end{array}$ & $\begin{array}{l}\text { Mixture of apple juice with mango } \\
\text { puree or orange, apple, pineapple, } \\
\text { passionfruit with banana puree }\end{array}$ \\
\hline $\begin{array}{l}\text { Goodbelly }{ }^{\circledR} \text { Carrot Ginger } \\
\text { Flavor (Goodbelly, USA) }\end{array}$ & L.plantarum $299 \mathrm{v}$ & $\begin{array}{l}\text { Carrot juice, ginger extract, and cane sugar } \\
\text { contains } 2 \% \text { or less gluten-free oat flour }\end{array}$ \\
\hline $\begin{array}{c}\text { KEVITA } \\
\text { (KEVITA, USA) }\end{array}$ & $\begin{array}{l}\text { L.rhamnosus, L.plantarum, } \\
\text { L.paracasei, } \\
\text { B. coagulans GBI-30 } 6086\end{array}$ & $\begin{array}{l}\text { Various fruit-based mixtures such as } \\
\text { strawberry and coconut, lime, mint } \\
\text { and coconut, pineapple and coconut }\end{array}$ \\
\hline $\begin{array}{l}\text { Malee Probiotics (Malee } \\
\text { Enterprise Company } \\
\text { Ltd., Thailand) }\end{array}$ & L.paracasei & Prune, grape and orange juice \\
\hline $\begin{array}{l}\text { PERKii Probiotic Water } \\
\text { (PERKii, Australia) }\end{array}$ & L.paracasei Lc431 & $\begin{array}{l}\text { Fruit juice mixtures such as raspberry and } \\
\text { pomegranate, lime and coconut, mango and } \\
\text { passionfruit and strawberry and } \\
\text { watermelon }\end{array}$ \\
\hline $\begin{array}{c}\text { Probiotic Naked Juice }\left(\text { Naked }^{\circledR}\right. \\
\text { Juice, USA) }\end{array}$ & Bifidobacterium & $\begin{array}{c}\text { Mixture of apple, orange, pineapple juices } \\
\text { and mango and banana puree with } \\
\text { fructooligosaccharides }\end{array}$ \\
\hline $\begin{array}{c}\text { ProViva } \\
\text { (EMEA Probi AB, Sweden) }\end{array}$ & L.plantarum $299 \mathrm{v}$ & $\begin{array}{l}\text { Orange, strawberry or blackcurrant juice } \\
\text { and fortified with } 5 \% \text { oat flour }\end{array}$ \\
\hline $\begin{array}{c}\text { Rela Fruit Juice } \\
\text { (Biogaia Global, Sweden) }\end{array}$ & L.reuteri MM53 & Fruit juice \\
\hline $\begin{array}{l}\text { Tropicana probiotics } \\
\text { (Tropicana, USA) }\end{array}$ & B.lactis & $\begin{array}{c}\text { Fruit juice mixtures such as strawberry and } \\
\text { banana, pineapple and mango, peach and } \\
\text { passionfruit }\end{array}$ \\
\hline $\begin{array}{c}\text { Vita Biosa } \\
\text { (Biosa, Denmark) }\end{array}$ & $\begin{array}{l}\text { B.lactis, B.longum, L.acidophilus, } \\
\text { L.casei, L.rhamnosus, L.salivarius, } \\
\text { L.lactis, Streptococcus thermophilus }\end{array}$ & $\begin{array}{c}\text { Ginger, blackcurrant, blueberry juice with } \\
\text { ginger extract enriched with } 19 \text { different } \\
\text { aromatic herbs }\end{array}$ \\
\hline
\end{tabular}

\section{The Case of Pomegranate Juice as Substrate for Probiotic Bacteria Fermentation}

Pomegranate (Punica granatum L.) and its juice exhibit high antioxidant capacity because of their rich polyphenol content. In comparison with other widely consumed fruit juices like grape, cranberry, grapefruit and orange juice, pomegranate juice demonstrated 3 times higher antioxidant capacity [23]. Ellagitannins and anthocyanins are the responsible substances for the observed antioxidant activity [24]. Punicalagins are the major ellagitannins in pomegranate and after the consumption of the fruit they can be hydrolysed to ellagic acid in vivo [25]. The amount of punicalagins contained in the juice depends on the fruit cultivar, processing and storage conditions [26,27]. The total phenolics calculated either with HPLC or with the Folin-Ciocalteu method is approximately $2500 \mathrm{mg} / \mathrm{L}$ [27].

Other chemical constituents in pomegranate juice include sugars (glucose, fructose, sucrose), organic acids (citric acid, malic acid, tartaric acid, fumaric acid, succinic acid, ascorbic acid, etc.), hydroxybenzoic acids, hydroxycinnamic acids, flavonoids and their glycosides (catechin, epicatechin, quercitin, rutin), aminoacids (proline, valine, methionine, glutamic acid, aspartic acid), indoleamines (tryptamine, serotonin, melatonin) and tocopherols [28,29]. Minerals in traces are also included, such as $\mathrm{Fe}, \mathrm{Ca}, \mathrm{Cl}, \mathrm{Cu}, \mathrm{K}, \mathrm{Mg}$, $\mathrm{Mn}, \mathrm{Na}$, $\mathrm{Sn}$ and $\mathrm{Zn}$.

The antioxidant capacity of pomegranate juice is of major significance for the agro-food industry because of the fact that it can be used as a natural biopreservative instead of synthetic antioxidants. The latter are frequently accused as having toxic side effects, meanwhile isomers of punicalagin, tannin derivatives and anthocyanins scavenge free radicals and inhibit lipid oxidation in vitro [25]. 
Commercial pomegranate juices showed an antioxidant activity (18-20 TEAC) three times higher than those of red wine and green tea [27].

Likewise, many scientific data have been published lately regarding lactic acid fermentation of pomegranate juice with probiotic bacteria. Mousavi et al. [12] used L. plantarum, L. delbrueckii, L. paracasei and L. acidophilus for the fermentation of pomegranate juice. The results demonstrated that L. plantarum and L. delbrueckii had higher viability levels during fermentation and storage time compared to the other $\mathrm{LAB}\left(2.8 \times 10^{5} \mathrm{cfu} / \mathrm{mL}\right.$ and $1.5 \times 10^{5} \mathrm{cfu} / \mathrm{mL}$ after the second week of storage, respectively). The maximum viability level was retained for two weeks storage and after the fourth week fell dramatically for both of the strains mentioned above. Authors concluded that pomegranate juice is a suitable medium for the production of a fermented probiotic drink.

The same authors [30] applied two probiotic strains of L. plantarum and L. acidophilus as starter cultures in pomegranate juice fermentation. Their viability in the juice reached to $3.07 \times 10^{8} \mathrm{cfu} / \mathrm{mL}$ and $3.9 \times 10^{8} \mathrm{cfu} / \mathrm{mL}$ respectively, after $72 \mathrm{~h}$ of fermentation. As far as the consumption of sugars is concerned, glucose degradation rate was higher than fructose. Lactic acid was the most abundant acidic metabolite. It was found that probiotic pomegranate juice had increased antioxidant activity. The free radical scavenging effect of the juice was increased through fermentation; however, the enhanced effect of fermentation varied with the employed bacteria since L. acidophilus improved the antioxidant capacity of the juice more extensively than L. plantarum.

In another assay, a yogurt drink was supplemented with different concentrations of inulin, as a prebiotic $(0 \%, 0.5 \%, 1 \%, 2 \%)$ and with pomegranate juice $(0 \%, 3 \%, 8 \%, 12 \%)$ [31]. The probiotic strain that was added for fermentation was L. casei 431. High levels of pomegranate juice addition resulted in high levels of antioxidant activity. Additionally, high levels of inulin resulted in low acidity and lactic acid amounts. Overall, supplementation with inulin and pomegranate juice had positive impact on $L$. casei viability. Especially for yogurt drink samples containing $12 \%$ juice, the mean value of viability was $7.93 \log \mathrm{cfu} / \mathrm{mL}$ compared to controls where the mean value was $7.11 \log \mathrm{cfu} / \mathrm{mL}$.

Sabkobar et al. [32] supplemented a mixture of pomegranate juice and whey with kefir grains. Two different fermentation temperatures $\left(19^{\circ} \mathrm{C}\right.$ and $\left.25^{\circ} \mathrm{C}\right)$ and level of kefir grains inoculum $(5 \%$ and $8 \% w / v)$ were examined through $32 \mathrm{~h}$ of fermentation. The best combination regarding the achievement of high viabilities was kefir grains inoculum $8 \%$ and $25{ }^{\circ} \mathrm{C}$ fermentation temperature. The sensorial characteristics of this novel probiotic dairy and fruit juice beverage were also acceptable.

Encapsulation of L. rhamnosus GG in whey protein microbeads has also been examined, as far as the probiotic protection is concerned, by Doherty et al. [33]. After encapsulation, storage studies were performed in cranberry and pomegranate juice in combination with ex vivo porcine gastric $(\mathrm{pH} 1.6)$ and intestinal digestion ( $\mathrm{pH}$ 6.6). During storage, results revealed that coated microbeads enhanced probiotic viability (approximately $8.6 \log \mathrm{cfu} / \mathrm{mL}$ ) and high gastric survival (approximately $9.5 \mathrm{log}$ $\mathrm{cfu} / \mathrm{mL}$ ) with $30 \mathrm{~min}$ delayed intestinal release in comparison to non-coated microbeads, justifying their role for targeted intestinal probiotic delivery.

Immobilization of probiotic bacteria was also applied in lactic acid fermentation of pomegranate juice. Specifically, L. paracasei K5 was immobilized on delignified wheat bran (DWB) and was used for pomegranate juice fermentation at three different $\mathrm{pH}$ values $(3.3,3.6,3.9)$ for $24 \mathrm{~h}$. Storage of the fermented pomegranate juice for 4 weeks at $4{ }^{\circ} \mathrm{C}$ followed. As proven, immobilization enhanced the viability of L.paracasei $\mathrm{K} 5$, especially at $\mathrm{pH} 3.9$ where the range varied between 9.8 and $11.7 \log \mathrm{cfu} / \mathrm{mL}$. The phenolic content of the produced beverage increased as well [34].

In addition, the co-culture of two different LAB (L.plantarum VITES07 and L.acidophilus NCIM2903) for the fermentation of pomegranate juice has been examined as well by Murthy et al. [35]. The initial viability value of the co-culture was $2.75 \times 10^{5} \mathrm{cfu} / \mathrm{mL}$ and reached the value of $6.75 \times 10^{5} \mathrm{cfu} / \mathrm{mL}$ after $72 \mathrm{~h}$ of fermentation at room temperature. Various organic acids were detected, including formic acid (antibacterial activity), oxalic acid (antitumor activity), tartaric acid (antioxidant activity), gallic acid (antifungal and antiviral activity), citric acid (preservative and flavor enhancer), vanillic acid (flavor enhancer), malic acid (flavor enhancer). These results indicate high antioxidant (initial value 
for raw pomegranate juice was 63\% and for fermented pomegranate juice, 79.84\%), antibacterial, and antitumor activities as well as polyphenol content (concentration for raw pomegranate juice was 75 $\mu \mathrm{g} / \mathrm{mL}$ and concentration for fermented pomegranate juice was $160 \mu \mathrm{g} / \mathrm{mL}$ ) for the pomegranate juice produced with fermentation with co-culture of the two probiotic strains.

Kazakos et al. [36] applied kefir grains for the fermentation of pomegranate juice alone or in combination with orange juice. Several parameters, such as sugar consumption, ethanol production, lactic acid formation and LAB viability were recorded during storage at $4{ }^{\circ} \mathrm{C}$ for 4 weeks. Results revealed that orange juice improved the fermentative activity of kefir grains and the viability of LABs during storage period. More specifically, $75 \%$ of the cells survived (6.48 $\log \mathrm{cfu} / \mathrm{mL})$ after 4 weeks of storage of the fermented mixed substrate, while only $24 \%$ of the cells survived when only pomegranate juice was fermented. Lactic acid formation was observed in respectable amounts, especially in the mixed substrates, indicating metabolic activity even during cold storage.

An assay of similar experimental design was conducted by Shubhada et al. [37], where pomegranate juice alone and blended with different proportions of kokum juice was fermented with L. plantarum, L. delbrueckii and L. acidophilus at $37^{\circ} \mathrm{C}$ for $72 \mathrm{~h}$. Acidity, antioxidant capacity, $\mathrm{pH}$, total phenol content and viability at cold storage $\left(4^{\circ} \mathrm{C}\right)$ conditions were examined. L. plantarum reached the highest population after 30 days at storage $\left(2 \times 10^{6} \mathrm{cfu} / \mathrm{mL}\right)$ as far as the viability is concerned. Fermented pomegranate juice exhibited enhanced antioxidant activity, acidity and total phenol content. As far as the sensorial evaluation of the produced beverage is concerned, the best scores were achieved by fermented beverage with $15 \%$ blend of kokum juice. The best results of antioxidant activity were indicated when $85 \%$ of pomegranate juice and $15 \%$ of kokum juice and L. plantarum was used $(77.07 \%)$ compared to the unfermented pomegranate juice with the respective value of $59.05 \%$.

From our team, three more research papers have been published lately. In the first two papers, a potential probiotic strain L. paracasei $\mathrm{K} 5$, previously isolated from feta-type cheese, was applied for pomegranate juice fermentation [38,39]. Fermentation for $24 \mathrm{~h}$ followed, and afterwards storage of pomegranate juice at $4{ }^{\circ} \mathrm{C}$ for 4 weeks occurred. Volatile composition appeared enhanced, probably because of the lactic acid fermentation, even after the fourth week of storage. Increased antioxidant activity was observed for all the storage times in comparison with the initial pomegranate beverage. The viability of the strain was retained in levels higher than $7 \log \mathrm{cfu} / \mathrm{mL}$ of juice in all time periods studied. Finally, the fermented beverage achieved a higher score by consumers compared to the unfermented juice.

In the third assay, the main differentiation with the previously mentioned research is that the probiotic strain applied for fermentation of the pomegranate juice was L. plantarum ATCC 14917 [40]. Fermented pomegranate juice exhibited higher percentages of viability, even at the fourth week of storage $(8.83 \log \mathrm{cfu} / \mathrm{mL})$, better volatile compound composition, higher antioxidant activity and total phenolic content compared to the unfermented juice. Finally, the fermented beverage achieved higher scores by consumers compared to the unfermented juice, in terms of aroma, taste and overall quality, especially during the 4th week of storage.

Similar findings have been recorded by Di Cagno et al. [41], who studied the lactic acid fermentation of pomegranate juice with Lactobacillus plantarum C2, POM1 and LP09. The fermented pomegranate juice exhibited higher concentrations of alcohols, ketones, terpenes, benzene derivatives and lower concentrations of non-desirable aldehydes. This chemical profile was associated in a second phase with the sensory features of fermented and unfermented pomegranate juices. A consensus modified flavor profile based on 13 attributes was followed and fermented samples were characterized by higher intensity of floral, fruity and anise notes compared to controls.

A comparative assay has taken place by Srisukchayakula et al. [42] regarding acidic fruit juices, such as cranberry ( $\mathrm{pH}$ 2.7), pomegranate ( $\mathrm{pH}$ 3.5) and lemon and lime ( $\mathrm{pH} 2.8$ ), that were evaluated for the survival of L. plantarum NCIMB 8826. The findings indicate that cells died more quickly in pomegranate juice compared to lemon and lime juice (4 weeks versus 5 weeks) despite the fact that the $\mathrm{pH}$ in the former was higher, probably because of the presence of phenolic compounds. Nevertheless, 
the pomegranate and the lemon and lime juice may be used as probiotic carriers, since they provide a friendlier environment for cells compared to cranberry juice.

In addition, studies with the application of pomegranate juice fermented with probiotic strains and in vivo experiments have also taken place. Esmaeilinezhad et al. [43] examined the impact of a pomegranate synbiotic (with L.rhamnosus GG bacillus koagolans indicous) juice on glycemic indices, sex hormone profile and anthropometric measurements in polycystic ovarian syndrome (PCOS) patients. In summary, this randomized, triple-blind, controlled trial showed that the synbiotic pomegranate beverage and its consumption improved some metabolic syndrome features including dysglycemia and anthropometric indices, and also reduced testosterone levels in women with PCOS. It should be underlined that a 12-week trial of synbiotics with inulin and a blend of Lactobacillus spp. and Bifidobacterium spp. could improve insulin resistance, body mass index (BMI), waist circumference and symptoms of hyperandrogenism.

In the same manner, fermented milk containing whey protein, B.animalis subsp. lactis BB12 and pomegranate juice was found to restore intestinal microbiota and protect rats from the undesirable effects of intense acute exercise. [44]. Specifically, the researchers observed that exercised rats exhibited a decrease in the proportion of Lactobacillus species and an increase in Clostridium species. Supplementation maintained the natural microbiota proportions of the exercised rats. Finally, the final product could be prospected to humans in acute exercise or in situations of hypermetabolic states, e.g., malnutrition.

\section{Feasibility of Pomegranate Juice Selection as Potential Substrate for Probiotic Delivery. Advantages and Drawbacks}

From all the above, it becomes clear that fermentation of pomegranate juice with bacteria is feasible and can lead to a novel functional beverage, mostly because of its saccharides content, which are necessary for the growth of probiotic bacteria, and due to high levels of bioactive compounds that display antioxidant, antimicrobial and antimutagenic properties [45-48]. More specifically, fermented pomegranate juice exhibits antimicrobial properties due to punicalins, ellagic acids and punicalagins [49] and due to the contribution of short-chain fatty acids with free hydroxyl groups [50]. In addition, the presence of probiotic bacteria in high levels in pomegranate juice contributes even more to the antimicrobial activities of the product and adds nutritional value. In particular, Lactobacillus spp. produce antifungal substances, like benzoic acid, methylhyolantoin, mevalonolactone and short-chain fatty-acids [51,52]. It is known that probiotics bind to toll-like receptors (TLR) under epithelial cells and release defensins from the cells in order to stabilize the function of gut barrier [53].

On the other hand, the main problems regarding lactic acid fermentation of pomegranate juice with or without probiotic bacteria are: (i) the preservation of viability in high levels, approximately 6-7 $\log \mathrm{cfu} / \mathrm{mL}$ at the time of consumption [54] and (ii) consumers' acceptance [21]. Cell viability is usually influenced by many parameters such as $\mathrm{pH}$ value, phenolic content and time and temperature of storage [13]. Temperature of storage or fermentation and agitation are also involved in the viability and stability of probiotics [54]. However, an acidic environment is considered the main problem for some fruit juices such as pomegranate. Pomegranate juice is considered as an acidic fruit and therefore this may lead to significant loss of probiotic viability [49]. This drawback can be tackled mainly in two ways: (i) the proper selection of probiotic wild-strain bacteria, able to survive under acidic conditions, and (ii) the application of microencapsulation methods such as immobilization. Regarding the proper selection of a probiotic strain, there are examples in the literature proving their impact. For instance, Shubhada et al. [37] studied the fermentation of pomegranate juice with various LAB (L. acidophilus, $L$. plantarum, and L. delbrueckii). Finally it was concluded that L. plantarum preserved its viability for 30 days. In addition, the application of L. plantarum c19 led also to high preservation of viabilities [13]. The same outcome was observed in the case of the application of a novel potential probiotic $L$. paracasei K5 by Plessas et al. [38]. 
Another way to overcome viability losses is the selection and mixing of pomegranate juice with another juice with higher $\mathrm{pH}$ values (above 4 ) compared to pomegranate juice. For instance, carrot juice has relatively high $\mathrm{pH}$ value $(\mathrm{pH}$ 6).

On the other hand, the application of probiotics immobilization on various food-grade carriers exhibiting prebiotic properties such as cereals seems to overcome viability losses [55]. It is well known that cereals exhibit prebiotic properties; likewise, they can enhance probiotic viability. Indeed, recently, immobilization of the probiotic L. plantarum ATCC 14917 and potential probiotic L. paracasei K5 on delignified wheat bran enhanced cell viability above levels required for probiotics during fermentation and cold storage of pomegranate juice [34,40].

The food industry and market cares not only for technological feasibility and health-promoting properties of a new probiotic formulate but also for its sensorial properties which defines consumer acceptance. Likewise, the sensory traits of the juices fermented with LAB should be faced due to the possible identification of probiotic off-flavors by consumers [56]. However, lactic acid fermentation of pomegranate juice has not revealed problems regarding the sensorial characteristics of the final product until now. A general explanation is that pomegranate juice contains high levels of aroma precursors, such as phenolic compounds, sugars and fatty acids, which are considered as good substrates for aroma compound production during lactic acid fermentation [57]. A more persisting explanation for this point was revealed by Di Gagno, et al. [41], who observed that lactic fermentation of pomegranate juice seems to increase the abundance of desired volatile compounds (mainly ketones) and limit the numbers of non-desired volatile compounds (mainly aldehydes). The same outcome was confirmed by our team $[34,40]$.

\section{Conclusions and Future Perspectives}

Pomegranate juice seems to offer a very good alternative option as a substrate for the delivery of probiotic bacteria to consumers who do not prefer dairy products. Lactic acid fermentation of pomegranate juice seems to (i) enhance its nutritional value and (ii) increase its preservation time compared to unfermented juice during cold storage for approximately 4 weeks. [58]. However, future work is needed in order to further optimize the lactic acid fermentation of pomegranate juice in terms of preservation of cell viability during cold storage and acceptable sensorial properties. In our opinion, a proposed strategy regarding the exploitation of pomegranate juice as a substrate for probiotic delivery should include the following steps (Figure 1): (i) probiotic bacteria should be immobilized in cereals exhibiting prebiotic properties and afterwards freeze dried for the achievement of higher preservation time, and (ii) pomegranate juice should be mixed with other fruit juices of higher $\mathrm{pH}$ values, in order to surpass its acidic conditions and simultaneously lead to better organoleptic properties.

\begin{tabular}{|c|c|c|}
\hline $\begin{array}{l}\text { Immobilized probiotic bacteria } \\
\text { with food substrates with } \\
\text { prebiotic properties (cereals) }\end{array}$ & Freeze drying & $\begin{array}{l}\text { Freeze dried immobilized } \\
\text { biocatalysts acting as starter } \\
\text { culture }\end{array}$ \\
\hline & & + \\
\hline $\begin{array}{l}\text { Production of a novel functional } \\
\text { beverage based on pomegranate } \\
\text { juice }\end{array}$ & $\begin{array}{l}\text { Lactic acid } \\
\text { fermentation }\end{array}$ & $\begin{array}{l}\text { Pomegranate juice (alone or } \\
\text { mixed with other juices) }\end{array}$ \\
\hline
\end{tabular}

Figure 1. Proposed diagram for functional pomegranate juice production through fermentation with probiotic bacteria. 
Author Contributions: Conceptualization: S.P., I.M., investigation: S.P., I.M. \& S.K., writing-original draft preparation: S.P. \& I.M., writing-review and editing: S.P. The three authors have approved the submitted version. All authors have read and agreed to the published version of the manuscript.

Funding: This research received no external funding.

Conflicts of Interest: The authors declare no conflict of interest.

\section{References}

1. Grajek, W.; Olejnik, A.; Sip, A. Probiotics, prebiotics and antioxidants as functional foods. Acta Biochim. Pol. 2005, 52, 665-671. [CrossRef] [PubMed]

2. Lee, J.; Chen, G.; Liang, L.; Wagna, C. Anti-inflammatory effects of Punica granatum Linne in vitro and in vivo. Food Chem. 2010, 118, 315-322. [CrossRef]

3. Hamad, W.; Al-Momene, W. Separation and purification of crude ellagic acid from white flesh of pomegranate fruits as a potent anti-carcinogenic. New Biotechnol. 2009, 25, 286. [CrossRef]

4. Duman, A.D.; Ozgen, M.; Dayisoylu, K.S.; Erbil, N.; Durgac, C. Antimicrobial activity of six pomegranate (Punica granatum L.) varieties and their relation to some of their pomological and phytonutrient characterisitcs. Molecules 2009, 14, 1808-1817. [CrossRef]

5. Plessas, S.; Bosnea, L.; Alexopoulos, A.; Bezirtzoglou, E. Potential effects of probiotics in cheese and yogurt production: A review. Eng. Life Sci. 2012, 12, 433-440. [CrossRef]

6. Cam, M.; Hisil, Y.; Durmaz, G. Classification of eight pomegranate juices based on antioxidant capacity measured by four methods. Food Chem. 2009, 112, 721-726. [CrossRef]

7. Haidari, M.; Ali, M.; Casscells, S.W.; Madjid, M. Pomegranate (Punica granatum L.) purified polyphenol extract inhibits influenza virus and has a synergistic effect with oseltamivir. Phytomed 2009, 16, 1127-1136. [CrossRef]

8. Quigley, M.E.; Hudson, G.J.; Englyst, H.N. Determination of resistant short-chain carbohydrates (non-digestible oligosaccharides) using gas-liquid chromatography. Food Chem. 1999, 65, 381-390. [CrossRef]

9. Gibson, A.; Glenn, R.; Roberfroid, A.; Marcel, B. Dietary Modulation of the Human Colonic Microbiota: Introducing the Concept of Prebiotics. J. Nutr. 1995, 125, 1401-1412. [CrossRef]

10. Crittenden, R.G.; Playne, M.J. Production, properties and applications of food-grade oligosaccharides. Trends Food Sci. Technol. 1996, 7, 353-361. [CrossRef]

11. Juśkiewicz, J.; Zduńczyk, Z.; Wróblewska, M.; Gulewicz, K. Influence of oligosaccharide extracts from pea and lupin seeds on caecal fermentation in rats. J. Anim. Feed Sci. 2003, 12, 289-298. [CrossRef]

12. Mousavi, Z.E.; Mousavi, S.M.; Razavi, S.H.; Emam-Djomeh, Z.; Kiani, H. Fermentation of pomegranate juice by probiotic lactic acid bacteria. World J. Microbiol. Biotechnol. 2011, 27, 123-128. [CrossRef]

13. Bevilacqua, A.; Campaniello, D.; Corbo, M.R.; Maddalena, L.; Sinigaglia, M. Suitability of Bifidobacterium spp. and Lactobacillus plantarum as Probiotics Intended for Fruit Juices Containing Citrus Extracts. J. Food Sci. 2013, 78, M1764-M1771. [CrossRef] [PubMed]

14. Capela, P.; Hay, T.K.C.; Shah, N.P. Effect of cryoprotectants, prebiotics and microencapsulation on survival of probiotic organisms in yoghurt and freeze-dried yoghurt. Food Res. Int. 2006, 39, 203-211. [CrossRef]

15. Sadeq, H.A.S.; Amin, I.; Mohd, Y.M.; Shuhaimi, M.; Rokiah, M.Y.; Fouad, A.H. Prebiotics as functional foods: A review. J. Funct. Foods 2013, 5, 1542-1553.

16. Liu, R.H. Health-Promoting Components of Fruits and Vegatables in the Diet. Adv. Nutr. 2013, 4, 384S-392S. [CrossRef]

17. Yang, X.; Zhou, J.; Fan, L.; Qin, Z.; Chen, Q.; Zhao, L. Antioxidant properties of a vegetable-fruit beverage fermented with two Lactobacillus plantarum strains. Food Sci. Biotechnol. 2018, 27, 1719-1726. [CrossRef]

18. Kaprasob, R.; Kerdchoechuen, O.; Laohakunjit, N.; Thumthanaruk, B.; Shetty, K. Changes in physic-chemical, astringency, volatile compounds and antioxidant activity of fresh and concentrated cashew apple juice fermented with Lactobacillus plantarum. J. Food Technol. 2018, 55, 3979-3990. [CrossRef]

19. Li, Z.; Teng, J.; Lyu, Y.; Hu, X.; Zhao, Y.; Wang, M. Enhanced antioxidant activity for apple juice fermented with Lactobacillus plantarum ATCC14917. Molecules 2019, 24, 51. [CrossRef]

20. Chaudhary, A. Probiotic Fruit and Vegetable Juices: Approach Towards a Healthy Gut. Int. J. Curr. Microbiol. Appl. Sci. 2019, 8, 2319-7706. [CrossRef] 
21. Patel, A.R. Probiotic fruit and vegetable juices-recent advances and future perspectives. Int. Food Res. J. 2017, 24, 1850-1857.

22. Molin, G. Probiotics in foods not containing milk or milk constituents, with special reference to Lactobacillus plantarum 299v. Am. J. Clin. Nutr. 2001, 73, 380-385. [CrossRef] [PubMed]

23. Mantzourani, I.; Terpou, A.; Alexopoulos, A.; Kimbaris, A.; Bezirtzoglou, E.; Koutinas, A.A.; Plessas, S. Production of a potentially symbiotic pomegranate beverage by fermentation with Lactobacillus plantarum ATCC14917 absorbed on a prebiotic carrier. Appl. Biochem. Biotechnol. 2019, 188, 1096-1107. [CrossRef] [PubMed]

24. Sirilun, S.; Sivamaruthi, B.S.; Kesika, P.; Peerajan, S.; Chaiyasut, C. Lactobacillus paracasei HII01 mediated fermentation of Syzygium cumini L. fruits: Aassessment of changes in phenolic content and antioxidant capacity. Asian J. Pharm. Clin. Res. 2018, 11, 304-308. [CrossRef]

25. Shukla, S.; Park, J.; Park, J.H.; Lee, J.S.; Kim, M. Development of Lotus Root sugar syrup as a functional food supplement/condiment and evaluation of its physicochemical, nutritional and microbiological properties. J. Food Sci. Technol. 2018, 55, 619-629. [CrossRef]

26. Seeram, N.P. Berry Fruits: Compositional Elements, Biochemical Activities, and the Impact of Their Intake on Human Health, Performance, and Disease. J. Agric. Food Chem. 2008, 56, 627-629. [CrossRef]

27. Gil, M.I.; Tomás-Barberán, F.A.; Pierce, B.H.; Holcroft, D.M.; Kader, A.A. Antioxidant Activity of Pomegranate Juice and Its Relationship with Phenolic Composition and Processing. J. Agric. Food Chem. 2000, 48, 4581-4589. [CrossRef]

28. Seeram, N.P.; Lee, R.; Heber, D. Bioavailability of ellagic acid in human plasma after consumption of ellagitannins from pomegranate (Punica granatum L.) juice. Clin. Chim. Acta 2004, 348, 63-68. [CrossRef]

29. Seeram, N.P.; Adams, L.S.; Hardy, M.L.; Heber, D. Total Cranberry Extract versus Its Phytochemical Constituents: Antiproliferative and Synergistic Effects against Human Tumor Cell Lines. J. Agric. Food Chem. 2004, 52, 2512-2517. [CrossRef]

30. Mousavi, Z.E.; Mousavi, S.M.; Razavi, S.H.; Hadinejad, M.; Emam-Djomeh, Z.; Mirzapour, M. Effect of Fermentation of Pomegranate Juice by Lactobacillus plantarum and Lactobacillus acidophilus on the Antioxidant Activity and Metabolism of Sugars, Organic Acids and Phenolic Compounds. Food Biotechnol. 2013, 27, 1-13. [CrossRef]

31. Nikmaram, P.; Mousavi, S.M.; Emam-Djomeh, Z.; Kiani, H.; Razavi, S.H. Evaluation and Prediction of Metabolite Production, Antioxidant Activities, and Survival of Lactobacillus casei 431 in a Pomegranate Juice Supplemented Yogurt Drink Using Support Vector Regression. Food Sci. Biotechnol. 2015, 24, 2105-2112. [CrossRef]

32. Sabokbar, N.; Khodaiyan, F. Characterization of pomegranate juice and whey based novel beverage fermented by kefir grains. J. Food Sci. Technol. 2015, 52, 3711-3718. [CrossRef] [PubMed]

33. Doherty, S.B.; Auty, M.A.; Stanton, C.; Ross, R.P.; Fitzgerald, G.F.; Brodkorb, A. Application of whey protein micro-bead coatings for enhanced strength and probiotic protection during fruit juice storage and gastric incubation. J. Microencapsul. 2012, 29, 713-728. [CrossRef] [PubMed]

34. Mantzourani, I.; Terpou, A.; Bekatorou, A.; Mallouchos, A.; Alexopoulos, A.; Kimbaris, A.; Bezirtzoglou, E.; Koutinas, A.A.; Plessas, S. Functional pomegranate beverage production by fermentation with a novel synbiotic L. paracasei biocatalyst. Food Chem. 2020, 308, 1256-1258. [CrossRef]

35. Murthy, S.N.; Patnaik, A.; Srinivasan, N.; Selvarajan, E.; Nivetha, A.; Mohanasrinivasan, V. Fermentative preparation of functional drink from Punica granatum using lactic acid bacteria and exploring its anti-tumor potential. Mater. Sci. Eng. 2017, 263, 22-45. [CrossRef]

36. Kazakos, S.; Mantzourani, I.; Nouska, C.; Alexopoulos, A.; Bezirtzoglou, E.; Bekatorou, A.; Plessas, S.; Varzakas, T. Production of Low-Alcohol Fruit Beverages Through Fermentation of Pomegranate and Orange Juices with Kefir Grains. Curr. Res. Nutr. Food Sci. 2016, 4, 19-26. [CrossRef]

37. Shubhada, N.; Rudresh, D.L.; Jagadeesh, S.L.; Prakash, D.P.; Raghavendra, S. Fermentation of Pomegranate Juice by Lactic Acid Bacteria. Int. J. Curr. Microbiol. Appl. Sci. 2018, 7, 4160-4173. [CrossRef]

38. Plessas, S.; Nouska, N.; Karapetsas, A.; Kazakos, S.; Alexopoulos, A.; Mantzourani, I.; Chondrou, P.; Galanis, A.; Bezirtzoglou, E. Isolation, characterization and evaluation of the probiotic potential of a novel Lactobacillus strain isolated from Feta-type cheese. Food Chem. 2017, 226, 102-108. [CrossRef]

39. Mantzourani, I.; Kazakos, S.; Terpou, A.; Mallouchos, A.; Kimbaris, A.; Alexopoulos, A.; Bezirtzoglou, E.; Plessas, S. Assessment of Volatile Compounds Evolution, Antioxidant Activity, and Total Phenolics Content 
during Cold Storage of Pomegranate Beverage Fermented by Lactobacillus paracasei K5. Fermentation 2018, 4, 95. [CrossRef]

40. Mantzourani, I.; Kazakos, S.; Terpou, A.; Alexopoulos, A.; Bezirtzoglou, E.; Bekatorou, A.; Plessas, S. Potential of the Probiotic Lactobacillus Plantarum ATCC 14917 Strain to Produce Functional Fermented Pomegranate Juice. Foods 2019, 8, 4. [CrossRef]

41. Di Cagno, R.; Filannino, P.; Gobbetti, M. Lactic acid fermentation drives the optimal volatile flavor-aroma profile of pomegranate juice. Int. J. Food Microbiol. 2017, 248, 56-62. [CrossRef]

42. Srisukchayakula, P.; Charalampopoulos, D.; Karatzas, K.A. Study on the effect of citric acid adaptation toward the subsequent survival of Lactobacillus plantarum NCIMB 8826 in low pH fruit juices during refrigerated storage. Food Res. Int. 2018, 111, 198-204. [CrossRef] [PubMed]

43. Esmaeilinezhad, Z.; Babajafari, S.; Sohrabi, Z.; Eskandari, M.-H.; Amooee, S.; Barati-Boldaji, R. Effect of synbiotic pomegranate juice on glycemic, sex hormone profile and anthropometric indices in PCOS: A randomized, triple blind, controlled trial. Nutr. Metab. Cardiovasc. Dis. 2019, 29, 201-208. [CrossRef] [PubMed]

44. Chaves, F.M.; Baptista, I.L.; Simabuco, F.M.; Quaresma, P.G.F.; Pena, F.L.; Bezerra, R.M.N.; Pauli, J.R.; da Cunha, D.T.; Campos-Ferraz, P.L.; Antunes, A.E.C. High-intensity-exercise-induced intestinal damage is protected by fermented milk supplemented with whey protein, probiotic and pomegranate (Punica granatum L.). Br. J. Nutr. 2018, 119, 896-909. [CrossRef] [PubMed]

45. Miguel, M.; Neves, M.A.; Antunes, M.D. Pomegranate (Punica granatum L.): A medicinal plant with myriad biological properties-A short review. J. Med. Plants Res. 2010, 4, 2836-2847.

46. Singh, B.; Singh, J.P.; Kaur, A.; Singh, N. Phenolic compounds as beneficial phytochemicals in pomegranate (Punica granatum L.) peel: A review. Food Chem. 2018, 261, 75-86. [CrossRef]

47. Shah, M.A.; Don Bosco, S.J.; Mir, S.A. Plant extracts as natural antioxidants in meat and meat products. Meat Sci. 2014, 98, 21-33. [CrossRef]

48. Kneifel, W. In vitro growth behaviour of probiotic bacteria in culture media with carbohydrates of prebiotic importance. Microb. Ecol. Health Dis. 2000, 12, 27-34. [CrossRef]

49. Nualkaekul, S.; Charalampopoulos, D. Survival of Lactobacillus plantarum in model solutions and fruit juices. Int. J. Food Microbiol. 2011, 146, 111-117. [CrossRef]

50. Topping, D.L.; Clifton, P.M. Short-Chain Fatty Acids and Human Colonic Function: Roles of Resistant Starch and Nonstarch Polysaccharides. Physiol. Rev. 2001, 81, 1031-1064. [CrossRef]

51. Prema, P.; Smila, D.; Palavesam, A.; Immanuel, G. Production and Characterization of an Antifungal Compound (3-Phenyllactic Acid) Produced by Lactobacillus plantarum Strain. Food Bioprocess Technol. 2010, 3, 379-386. [CrossRef]

52. Magnusson, J.; Schnürer, J. Lactobacillus coryniformis subsp. coryniformis Strain Si3 Produces a Broad-Spectrum Proteinaceous Antifungal Compound. Appl. Environ. Microb. 2001, 67, 1-5.

53. Furrie, E.; Macfarlane, S.; Thomson, G.; Macfarlane, G.T. Toll-like receptors-2, -3 and -4 expression patterns on human colon and their regulation by mucosal-associated bacteria. Immunology 2005, 115, 565-574. [CrossRef] [PubMed]

54. Hedberg, M.; Hasslöf, P.; Sjöström, I.; Twetman, S.; Stecksén-Blicks, C. Sugar fermentation in probiotic bacteria-An in vitro study. Oral Microbiol. Immunol. 2008, 23, 482-485. [CrossRef] [PubMed]

55. Schoina, V.; Terpou, A.; Bosnea, L.; Kanellaki, M.; Nigam, P.S. Entrapment of L. casei ATCC393 in the viscus matrix of Pistacia terebinthus resin for functional myzithra cheese manufacture. LWT Food Sci. Technol. 2017, 89, 441-448. [CrossRef]

56. Luckow, T.; Sheehan, V.; Fitzgerald, G.; Delahunty, C. Exposure, health information and flavourmasking strategies for improving the sensory quality of probiotic juice. Appetite 2006, 47, 315-323. [CrossRef]

57. Szutowska, J. Functional properties of lactic acid bacteria in fermented fruit and vegetable juices: A systematic literature review. Eur. Food Res. Technol. 2020, 246, 357-372. [CrossRef]

58. Fernandes Pereira, A.L.; Rodrigues, S. Chapter 15-Turning fruit juice into probiotic beverages. In Fruit Juices; Rajauria, G., Tiwari, B.K., Eds.; Academic Press: San Diego, CA, USA, 2018; pp. $279-287$.

(C) 2020 by the authors. Licensee MDPI, Basel, Switzerland. This article is an open access article distributed under the terms and conditions of the Creative Commons Attribution (CC BY) license (http://creativecommons.org/licenses/by/4.0/). 